\title{
15
}

\section{Urban Land in Solomon Islands: Powers of Exclusion and Counter-Exclusion}

\author{
Joseph D. Foukona and Matthew G. Allen
}

\section{Matthew Allen: Personal Journey}

In the middle of 2017 I finally fulfilled my longstanding ambition of getting a job at the University of the South Pacific (USP). Balancing family and working life is never straightforward, but in 2016 the stars started to align, as they say. My wife was offered a diplomatic posting to Suva and my son graduated from high school in Canberra at the end of the year. I also became aware that a position at USP for which I was qualified would be advertised in 2017. The time was right. So we took the plunge and moved to Suva at the beginning of 2017. I became a visiting fellow at the School of Government, Development and International Affairs (SGDIA), where I now hold the position of Director of Development Studies, and I continued to work part time for The Australian National University (ANU) during 2017.

My engagements with SGDIA throughout 2017, including a six-week staff exchange with my colleague Gordon Nanau under the auspices of the USP-ANU Memorandum of Understanding (he went to ANU to focus on his research while I taught one of his courses at USP), very much strengthened my desire to work with the school. It is one of the most supportive and collegial work environments I have ever encountered-a testament to the outstanding leadership of Sandra Tarte and, before her, Vijay Naidu. I was absolutely delighted to be offered the position in the middle of 2017. 
In many ways, arriving at USP has been the logical next step in my academic journey. Before joining USP, my entire scholarly career, both as a student and an academic, had been spent at ANU. With each successive research project in Pacific studies, my focus has, in a sense, jumped scales: from an MSc thesis investigating the human geography of a small island in Vanuatu (Malo) to a PhD study exploring the causes of the 1998-2003 conflict in Solomon Islands, to an Australian Research Council Discovery Early Career Researcher Award (DECRA) project looking at the political ecology of large-scale mining in Bougainville and Solomon Islands.

In coming to USP I have relished the opportunity to lift my gaze to the regional scale. This has been extraordinarily refreshing and invigorating, a wonderful learning experience. As the giants of Pacific studies - scholars such as Epeli Hau'ofa, Greg Fry and Margaret Jolly - have shown us, this vantage point is critically important, and it goes without saying that the view of Oceania from Suva could not be more different from the view from Canberra! Indeed, at times they appear irreconcilable.

This goes to the heart of why our USP-ANU relationships and partnerships are so vitally important. They work to bridge these different vantage points and conceptions of the region; to foster understanding, empathy and mutual respect. Now, arguably more than ever before, these two great centres of Pacific studies must work together to respectfully, ethically and competently provide the knowledge base required to assist our Pacific leaders to navigate the region through a rapidly changing and increasingly complex world.

\section{Joseph Foukona: Personal Journey}

I am a Solomon Islander of Malaitan heritage, a lawyer who has extensive knowledge and experience in land legislation and reform in the Pacific Islands. I am currently a senior lecturer and member of the editorial board for the Journal of South Pacific Law. I joined the University of the South Pacific's School of Law in Port Vila, Vanuatu, in 2004. My teaching, research and publications focus on land law, customary land tenure, Pacific legal history, land and development, traditional governance, climate change displacement and urbanisation in the Pacific Islands, especially Melanesia. I have been active as a facilitator of land and governance awareness programs in Solomon Islands. 
I have worked with international organisations and the Solomon Islands government on a number of projects. These include working with the Solomon Islands Law Reform Commission on low- and high-water mark legislation. In 2011, I led a team of local researchers on a World Bank pilot research project on access to advisory resources by parties to customary land dealings and natural resources access agreements in Solomon Islands as well as being involved in a study on land law and the UN program on Reducing Emissions from Deforestation and Forest Degradation (REDD) in Solomon Islands. I completed a PhD at ANU on land reform and legislation in Solomon Islands, graduating in July 2018. During my time at ANU, I was involved in a number of research projects on Solomon Islands through the State, Society and Governance in Melanesia program (now Department of Pacific Affairs) such as land reform in 2015 and urbanisation in 2016.

Foukona, J. D. and M. G. Allen 2017. Urban Land in Solomon Islands: Powers of Exclusion and Counter-Exclusion. In S. McDonell, M. G. Allen and C. Filer (eds), Kastom, Property and Ideology: Land Transformations in Melanesia. Canberra: ANU Press.

Republished with the kind permission of ANU Press.

\section{Introduction}

Donovan Storey has observed that urban growth in Melanesia 'has created an unabated demand on services, shelter, infrastructure and land-all of which are in limited supply' (Storey 2003:259). There can be no doubt that the supply of, and demand for, land as a commodity is a salient driver of exclusion from land in urban Honiara, the capital of Solomon Islands. In keeping with this volume's mandate to engage with the Powers of Exclusion framework developed by Derek Hall, Philip Hirsch and Tania Murray Li (2011), we apply it, first, to an analysis of the processes by which people-both settlers and those 'indigenous' to the island of Guadalcanal, which hosts Honiara-are being prevented from accessing urban land; and second, to an analysis of the strategies that the subjects of this exclusion are employing to claim, or claim back, access to land within the city boundaries. In other words, we are interested in examining powers of both exclusion and counter-exclusion as they apply to contemporary Honiara. In doing so, we suggest that the powers of exclusion and counter-exclusion at play in Honiara can only be fully understood against the backdrop of an encompassing political economy 
characterised by patronage networks and personalised forms of political and administrative governance; and with reference to the particular histories and social relations of Solomon Islands.

That said, we find much of heuristic value in Hall, Hirsch and Li's framework. Of the four powers of exclusion they identify-regulation, force, the market and legitimation-regulation and the market (and, to a much lesser extent, force) provide useful lenses on the processes of exclusion that are playing out in Honiara. In the case of powers of counter-exclusion (Hall et al. 2011:170-91), we find that legitimation plays a central role, as evidenced by collective mobilisations around discourses such as indigeneity, customary landownership, nation-building and citizenship. While force has not, to date, emerged as a salient power of counter-exclusion in urban Honiara, contemporary urban land struggles are set against the backdrop of the so-called 'Ethnic Tension' of 1998 to 2003, which saw the violent eviction of settlers from rural and periurban areas immediately adjacent to Honiara at the hands of Guadalcanal militants whose agenda could be broadly characterised as 'ethno-territorial' (ibid. 175-80). In the contemporary post-conflict setting, lingering tensions and grievances, including in relation to the original alienation of the land that now hosts Honiara, cast a spectre of violence over the city. Moreover, the increasingly violent character of Honiara's settlements, most of which are organised along ethnic lines, and previous incidents involving the mobilisation of settlement youth in overt acts of collective political violence, raise the possibility that force could yet become more salient as a power of counter-exclusion in urban Honiara.

In applying the Powers of Exclusion framework to our examination of processes of exclusion in urban Honiara, and in particular to the interaction between regulation and the market, we arrive at a broadly similar set of conclusions to those reached by Hall, Hirsch and Li, namely that the formal rules often bear little resemblance to on-the-ground realities (ibid. 16); that public officials frequently 'act as tyrants' in the administration of land (ibid.:14); and that the market for land is not a product of 'some abstract space of supply and demand' (ibid.:18). We demonstrate how the abuse of discretionary powers vested in the Commissioner of Lands has seen property rights in urban land allocated in ways that distort the market and abrogate formal legal procedures. Once such allocations have been made, the courts have tended to rule in favour of registered titleholders, and, on occasion, these rulings have been enforced by the state's security apparatus. It is within this realm-the 'fuzzy zone of compromise, accommodation 
and bribery' (ibid.:16) — that Solomon Islands' distinctive political economy, characterised by patronage networks and highly personalised forms of political and administrative governance, becomes paramount in understanding how exclusion plays out in urban Honiara.

Moreover, this political economy is also evident in some of the powers of counter-exclusion. We shall elucidate cases in which settlers have been able to successfully mobilise political and patronage networks in order to secure their access to urban land. Counter-exclusion has also seen the deployment of discursive strategies that are familiar from Southeast Asia-for example, in competing narratives of settlers as citizens and nation-builders, on the one hand, and the rights of indigenous people on the other (Allen 2012). But again, these discourses are inflected by the particular histories and social relations of Solomon Islands. For example, the discourse of customary landownership (Filer 1997), which we conceptualise as sitting at a scale below indigeneity (which, in the case of Solomon Islands, is often nested at the scale of the island or province), has become a powerful ideology of both exclusion and counterexclusion while settler narratives, especially those of the nation's largest group of migrant-settlers-Malaitans - are firmly rooted in histories of labour migration and workers' struggle. We also demonstrate how settler narratives of counter-exclusion have recently begun to invoke the colonial construct of 'waste lands', with its obvious connections to the overarching discursive themes of citizenship and nation-building.

We begin by discussing the historical context of Honiara and the rapid expansion of the city and its settlements that has occurred over the past several decades. We then examine the processes by which people have been excluded from accessing land in urban Honiara, focusing on the role of the Commissioner of Lands in both abrogating legal processes and distorting the urban land market. We then move to an analysis of the ways in which groups and individuals, including both settlers and indigenous landowners, have sought to counter their exclusion from the urban space. We conclude by reflecting upon the utility of the Powers of Exclusion framework in the case of urban Honiara and by discussing a recent change to the law designed to curb the discretionary powers of the Commissioner of Lands. 


\section{Historical Context of Honiara}

The Honiara landscape once upon time was under customary land tenure. The tenure arrangements were in accordance with the rules of custom. The rights to customary land were exercised by individuals, a family or group who belong to a clan or tribe (Allan 1957). How a person accessed customary land was through membership of a line, tribe or clan. Access and use of customary land could also be allowed based on special arrangements such as compensation, marriage, warfare or gifts (Zoleveke 1979). However, in the case of Honiara, the customary landscape changed over time into an urban space as a consequence of land alienation prior to and during the colonial period.

The site of the present city of Honiara was 'partly occupied by the village of Mataniko which consisted of a group of leaf houses' (BSIP 1968:5). The alienation of this core landscape originates from three land transactions negotiated between traders and people categorised as landowners prior to the establishment of Solomon Islands as a British Protectorate in 1893 (Moore 2013). The core area from Lunga to Point Cruz, referred to as Mataniko, was alienated through sale by Woothia (or Uvothea), Chief of Lunga, Allea, Chief of Nanago, and the latter's son, Manungo, to Thomas Gervin Kelly, John Williams and Thomas Woodhouse (who were trading partners) for $£ 60$ of trade goods in November 1886 (Moore 2013; WPHC n.d.). The other area to the west, bordering on Point Cruz, referred to as Ta-wtu (or Mamara plantation), was alienated to Karl Oscar Svensen and his partner Rabuth. The third land transaction was the alienation of the 'area to the east, named "Tenavatu"' to William Dumply, an employee of Svensen (Moore 2013).

These land areas were further alienated by the traders to other commercial actors, such the Levers plantation company, following the introduction of a leasing system by the colonial government soon after 1893 . This process of alienation resulted in the exclusion of the original landowners from their land because of the new owners asserting their property rights. These land alienation processes have been sources of contestation since the 1920s, which resonates with Colin Filer's concept of a 'double movement' of property rights in the context of Papua New Guinea. He argues that 'steps taken towards the partial or complete alienation of customary rights are continually compensated or counter-balanced by steps taken in the 
opposite direction, towards the reassertion of such rights' (Filer 2014:78). The double movement provides a useful framing for the ongoing assertion and reassertion of claims to land in and around Honiara.

The Kukum or Mataniko land, the core land area where Honiara is situated, was contested by landowners as an unfair purchase and this was investigated by Gilchrist Gibbs Alexander, who was appointed in 1919 as Lands Commissioner to investigate previous land alienations in the Protectorate. ${ }^{1}$ The Lands Commission recommended that the land claim be settled as follows:

(a) A survey should be made at the expense of Levers Pacific Plantation Ltd of all land to the east of the Matanikau River, all such land to be included in the title of the company, the Matanikau river to be the western boundary and the line run south west from Ilu to the back boundary of the Matanikau river; (b) the land to the west of the Matanikau River including all coconut trees planted by Levers Pacific Plantation Ltd to revert to native custom owners and to be excluded from the title of the [company]; (c) the natives to move the village of Matanikau to the west of the Matanikau river but to have the produce of the native gardens on the east side of the river so long as the present crops are bearing; (d) Levers to pay 50 pounds to the natives; (e) on completion of the survey a validating Regulation should be passed confirming the freehold title of Levers in the land shown on the survey plans as finally approved by the Resident Commissioner (WPHC 1922).

The Secretary of State confirmed this recommendation by publishing it in the Pacific High Commission Gazette in 1924, which gave it a force of law. This state-sanctioned process legitimated the property rights of Levers Pacific Plantation Ltd. It also authorised the return of land to the west of the Mataniko River to landowners.

Honiara did not exist prior to 1942 . The decision by the colonial administration to relocate the capital from Tulagi to Honiara appeared to be influenced by a number of factors. One was the existence of critical infrastructure left behind by the departing United States forces in 1945, such as the airfield at Henderson. Another was the 'anticipated agriculture potential of the Guadalcanal Plains and the dry healthy nature of the climate' (Bellam 1970:70). During this period, Honiara was an

1 Alexander resigned towards the end of 1920 after investigating 29 out of 55 land claims. He was replaced by Frederick Beaumont Philips to complete the work of the Land Commission, which then became known as the Philips Commission. 
'underpopulated and largely alienated hinterland' (ibid.). The land area on the east side of the Mataniko River, which was alienated by Levers Pacific Plantation Ltd and held as a freehold estate title known as Kukum, was acquired by the colonial administration in 1947 through a land acquisition process prescribed by law. The colonial administration acquired the land to the west of the Mataniko River through a process of negotiation with landowners who occupied it. Consequently, the landowners relocated to the fringes of the Honiara town boundary and the state assumed a 'monopoly of ownership of land in Honiara. On this clean new tenurial slate the capital was built' (ibid.:70).

However, in 1964, Baranamba Hoai of Mataniko village disputed the state's title to land comprising the Honiara town. He made a claim on behalf of himself and the Kakau and Hebata lines of Mataniko village, reasserting ownership rights over a part of the Honiara town land. Hoai and four others gave evidence to substantiate their land claim. But the Registrar of Titles rejected the claims on the basis of a lack of prima facie evidence and forwarded the case for decision by the Western Pacific High Court. In his ruling, Chief Justice G. G. Briggs also rejected Hoai’s claim due to lack of reliable evidence. The High Court further held that Hoai's claim was the same claim that was settled in 1924, and remained binding on the parties concerned (Anon. 1964; Moore 2013). To this day, this remains the key court decision that legitimises the state's property rights to land in Honiara.

\section{Post-War Migration and the Growth of Honiara's Settlements}

Due to Honiara's status as a city situated on alienated land over which the state has proprietary rights, it has attracted migrants from other islands to be part of this state landscape. The pattern of internal migration was influenced by the uneven distribution of development and social and economic opportunities. The concentration of education, medical and employment opportunities in Honiara and the surrounding areas of north Guadalcanal was a major factor in attracting people to the island of Guadalcanal. 
Although people from various islands have migrated and settled in Honiara, the largest number have come from Malaita (Gagahe 2000:53, 63-65). This is because it was Malaitan labour that was exploited in the development projects that took place on Guadalcanal, in the Western Solomons, and in other parts of the country. Part of the reason was that Malaita had a bigger population that could supply labour to the colonial plantations and, later, to the industries in Honiara. John Connell, in a study commissioned by the former South Pacific Commission (now the Secretariat of the Pacific Community), pointed out that migration to Guadalcanal and the Western Solomons was high in the period from 1978 to 1981 because of the employment opportunities available in these two provinces (Connell 1983). Nicholas Gagahe also noted that, according to the 1970, 1976 and 1986 national censuses, Malaita had a large number of out-migrants to Honiara, Guadalcanal, and Western and Central Provinces (Gagahe 2000:53, 63-65).

This has resulted in an increasing number of informal Malaitan settlements located in every corner of Honiara. Most of these settlements evolved from the temporary housing schemes that were introduced in the 1960s and their names reflect their ethnic composition based on either dialect or regions of Malaita. For instance, settlements in Honiara having Malaita dialect names are Ada'liua, Aekafo, Fera'ladoa, Matariu, Koa Hill, Lau Valley, Kwaio Valley, Fulisango and Tolo. Other settlements that comprise a mixture of people from various regions of Malaita include Burns Creek, Sun Valley, Borderline, New Mala, Kobito (1, 2 and 3), Green Valley, Gilbert Camp, Kaibia and Mamulele. While these settlements lack a guarantee of tenure security, with their residents therefore susceptible to processes of exclusion, some residents have built permanent houses and have subsequently successfully applied to the Commissioner of Lands to transfer the fixed-term estate title to them. We discuss this further in a later section of the chapter.

In 1960, the state introduced temporary housing area (THA) schemes on public or state land within the Honiara town boundary to cater for the influx of people to the town and to address the emergence of squatter settlements (Storey 2003). People were allowed to settle on public land and build temporary housing for a nominal fee of SB $\$ 5$ or $S B \$ 10$ per annum for a temporary occupation licence (TOL) (Tozaka and Nage 1981:115-18; Storey 2003). The system was intended to provide 
people some form of legal security in relation to urban land use while simultaneously discouraging 'large scale illegal settlement on other urban lands' (Storey 2003:269).

By the mid-1980s, 'THAs accommodated 23 per cent of Honiara's population ... those THAs outside the town's boundaries numbered around 15, with an estimated population of 1,308 persons' (Storey 2003:269). Over the years, however, the THA system has broken down, due in part to the significant increase in rural-urban migration. Other factors that have contributed to its decline include inadequate town planning, unaffordable housing and the maladministration of urban land. A household survey in 2006, funded by AusAID through the Solomon Islands Institutional Strengthening Lands and Administration Project, reported that only 10 of the 3,000 households surveyed had a valid TOL.

During the Ethnic Tension, which was mainly restricted to the island of Guadalcanal, some 30,000 settlers, most of whom were of Malaitan origin, were violently evicted from their places of residence in the rural and peri-urban areas west and especially east of Honiara. These displaced people either returned to Malaita or sought refuge in Honiara, where the city boundaries were secured by police and Malaitan militias. In the wake of the Ethnic Tension, Malaitan settlers have been unwilling to return to their former homes in rural and peri-urban Guadalcanal, even in the case of those who had obtained legal titles to land (Allen 2012). Honiara, on the other hand, continues to be seen as a safe and legitimate space to take up residence- $\mathrm{a}$ factor that has contributed to the rapid growth of both the city and its settlements since the restoration of peace and law and order in mid-2003.

Occupying an area of only 22.73 square kilometres, Honiara is easily the largest urban centre in Solomon Islands, accounting for around 78 per cent of the total urban population. The 2009 census recorded the city's population as 64,606 , which increases to around 80,000 when its peri-urban fringes are included (Allen and Dinnen 2015:391). Honiara's population has increased fivefold since Independence in 1978 (Moore 2015) and there are now around 30 informal settlements within the town boundary, six of which have encroached on customary land (Hou and Kudu 2012). Most of the residents in these settlements are considered as 'squatters' in the eyes of the state and city authorities because they 'lack legal title to the city land they occupy' (Englund 2002:141). 


\section{Powers of Exclusion in Contemporary Honiara}

Drawing upon the Powers of Exclusion framework, we see regulation, the market and, to a lesser extent, force as the key drivers of exclusion in contemporary Honiara. However, as we shall demonstrate below, the two main powers of exclusion considered here-regulation and the market-can only be understood with reference to a political economy characterised by patronage relations and the personalised nature of political and administrative practices. Exclusion from land in Honiara is produced through a dynamic interaction between regulation, the market and social and power relations that resonates strongly with the observation that the formal rules governing land and property rights often bear little resemblance to on-the-ground realities (Hall et al. 2011). We now consider each of the powers of exclusion in turn, but within a cross-cutting context of political economy.

\section{Regulation}

Title to Honiara city land is vested in the state as perpetual estate regulated by the Land and Titles Act. Following the definition of regulation in the Powers of Exclusion framework, this legislation governs which 'individuals, groups or state agencies have rule-backed claims to any particular piece of land' (Hall et al. 2011:16). Under this legislation, the state has exclusive property right claims to Honiara city land by vesting perpetual estate titles in the Commissioner of Lands, who holds them in trust for the state.

This means that the Commissioner of Lands, as an agent of the state, has exclusive legal right to determine Honiara city land use, to benefit from the services of this land, and to transfer portions of the property rights at mutually agreeable terms. He has the legal right to dispossess people, or turn individual claimants without legal titles into squatters:

Private property in land, other than customary land, is created by the Commissioner making a grant out of a perpetual estate over public land ... [and the] derivate interests, technically terms of years, are called Fixed Term Estates. The Commissioner of Lands is also responsible for approving all transfers of Fixed Term Estates and for approving long subleases (Williams 2011:2). 
This process of allocating private property rights depends entirely on the Commissioner of Lands' discretionary powers. These discretionary powers have been interpreted as giving him the authority to transfer or allocate plots of Honiara city land to private individuals, politicians or investors, regardless of the merits of such allocations. There have been numerous instances of the Commissioner of Lands exercising his discretionary powers in ways that appear to be beyond the textual legal meaning of how such powers should be exercised as prescribed by the Land and Titles Act. For example, the Honiara City Mayor, Andrew Mua, was reported on 7 June 2013 as complaining that the Commissioner of Lands had sold plots of land that were part of the Honiara dumpsite to Asian investors and other individuals (Namosuaia 2013).

The print media also reported that a small park in the centre of Point Cruz was allocated for transfer to a businessman. The Solo Environment Beautification Group claimed that they had started making a garden in the park after receiving assurance from the Permanent Secretary of the Ministry of Lands, Housing and Survey that the land would not be sold because drainage and sewerage lines lay under the area (Namosuaia 2013). Officers from the ministry, however, advised the group to stop any gardening work because the land had been sold for a commercial purpose. In August 2013, the media reported that a plot of land next to the Mataniko bridge, which had been set aside for possible future expansion of this urban transport infrastructure, was transferred by the Commissioner of Lands to an Asian businessman (Dawea 2013).

These examples show how the Commissioner of Lands' exercise of discretion, as provided by law, can easily be manipulated by 'uncodified and informal socio-political forces' (Pelto 2013). While the exercise of discretion by the Commissioner of Lands over urban land is often alleged to be an abuse of discretionary powers, there have been few court challenges or prosecutions. What is certain, however, is that the abuse of these discretionary powers has meant that a majority of Solomon Islanders find it challenging to acquire property rights in Honiara. This has seen the emergence over time of a range of strategies to acquire property rights in Honiara, which we discuss in the second part of this chapter as an instance of the powers of counter-exclusion.

The continual media reports and public complaints to the effect that the Commissioner of Lands has repeatedly abused his discretionary powers by leasing Honiara city land to politicians and investors for his own benefit 
has resulted in a recent amendment of the Land and Titles Act as part of the government's land reform program. This legislative amendment abolished the discretionary powers of the Commissioner of Lands and provides the Land Board with the 'powers and functions relating to the allocation of interest in land, the development of land and to ensure the administration of land is carried out in a fair, transparent and equitable manner'. ${ }^{2}$ We return to this recent development in the conclusion.

\section{The Market}

The market as a process of exclusion establishes land as a commodity that can be bought and sold. The market depends on regulation to define the process of ownership and legal title to the city land that residents occupy. The land in Honiara has been accessed, controlled and leased for government and commercial offices, private homes, stores, hotels and small-scale business. With the rapid increase in rural-urban migration and population growth, land supply as a marketable commodity in Honiara has become a limited resource. As a result, within and around Honiara, people coming from other parts of the country continue to struggle to acquire private property.

One reason is that the government insiders, or those associated with the Ministry of Lands, Housing and Survey, have secured patches of land within the Honiara town boundary and are transferring their property rights to these lands at very high market values that are only affordable to the highest income earners and investors. There have been constant allegations from the public that numerous officers in the Ministry of Lands, including the office cleaner, have more than one fixed-term estate title to land in Honiara. This suggests that these lands officers know the system well and are heavily involved in land deals by inflating land market prices. The consequence of this is the exclusion of many low or middleclass Solomon Islanders-who make up the majority of the Honiara population-from acquiring property rights because they cannot afford the increasing price of urban land.

Individual market transactions in land are occurring in Honiara at price levels that many Solomon Islanders cannot afford. For example, in 2010, the Premier of Guadalcanal, when commenting on the sale of

2 Section 8A, Land and Titles (Amendment) Act 2014. 
plots of land in the Lunga area, stated 'We learn that there are parcels of land sub-divided and registered and are ready for sale [that] are very expensive for potential individuals and business investors' (Palmer 2010). He recommended that Levers Solomon Limited, which holds the fixedterm estate title to the land in the Lunga area, 'reduce the current value of land sales at reasonable and affordable prices for individuals and businesses who would want to invest in Guadalcanal Province' (Palmer 2013). These land transactions are unregulated, so individuals or groups could easily be excluded by those with fixed-term estate titles due to unregulated market competition.

\section{Force}

Force, as a process of exclusion, concerns acts or threats of violence such as forceful eviction (Hall et al. 2011:4-5; see also McDonnell 2013). The Commissioner of Lands, as an agent of the state, and the Honiara Town Planning Board are the main actors who play an important role in determining people's access to, and development of, Honiara city land, including when to decide on the application of force as a process of exclusion.

Section 5 of the Town and Country Planning Act provides that there shall be a Town and Country Planning Board in each Province and in Honiara'. The Honiara Board has jurisdiction to establish a planning scheme and to regulate any development within the Honiara town boundary, including any material change of use of any building or land. The legislation prescribes that the Board must consider the planning scheme apart from any other material consideration when considering applications for building permits or any development within the Honiara town boundary (Foukona and Paterson 2013). However, 'the enforcement of planning requirements is, in practice, not very strong' (ibid.:75). This has given many people the impression that, as citizens, it is legitimate to first construct buildings on any vacant plot of land or any Honiara city land they have acquired and later apply for building permits if they are required by the Board to do so.

Due to the increase in informal settlements and the construction of houses without proper building permits, the Honiara City Council has recently started issuing notices to demolish such buildings as a measure to enforce its regulations (Namosuaia 2014). For example, an Asian businessman continued to build on a patch of land on the western side 
of the Mataniko bridge despite the Honiara Board turning down his proposed development application (Piringi 2013a). However, a Honiara city councillor challenged the decision of the Board, claiming that it was legitimate for the Asian businessman to develop the site because it was 'given by the Minister of Lands, Housing and Survey, Joseph Onika, who was one of the joint owners of that fixed term estate' (Piringi 2013b). The strategy used by the private businessman was to use the Honiara city councillor to challenge the decision of the board, and to highlight that the Minister of Lands, Housing and Survey was involved by leasing this land to the businessman, and thus it was legitimate. However, the board stood its ground and issued an order for the private business investor to demolish his building.

The decision of the board concerned the demolition of the private business investor's building rather than the title to the land. Once the Commissioner of Lands exercises his power in leasing urban land and a registered title is created, the property rights of the owner of registered title are indefeasible, ${ }^{3}$ or 'not liable to be defeated except as provided by the Land and Titles Act'. ${ }^{4}$ As highlighted by the Solomon Islands High Court:

once a person becomes registered owner of an interest under the Act, he has absolute liberty to deal with that interest according to the title which attaches to it under the Act. An innocent party ... is not bound to look beyond the register. ${ }^{5}$

Although the discretionary power of the Commissioner of Lands to create property rights has been questionable, and in some instances aggrieved settlers have challenged it, in most instances the courts in Solomon Islands have upheld the proprietary rights of the registered owner of land within the Honiara town boundary.

One example is the case of Keev. Matefaka, ${ }^{6}$ in which the defendants in this case were five families who had occupied and built semi-permanent houses on land the Commissioner of Lands had allocated to two Asian investors, Sia Kee Ching and Lau Khing Hung (Theonomi 2014).

3 The principle of indefeasibility and the conclusiveness of the register are covered under Parts VIII and IX of the Land and Titles Act.

4 Lever Solomon Ltd v. Attorney General (2013) SBCA 11. All court judgments cited in this chapter are available from www.paclii.org.

5 Manepora'a v. Aonima (2011) SBHC 79.

6 Kee v. Matefaka (2014) SBHC 112. 
These two investors applied to the Solomon Islands High Court in order to evict the defendants from the land. The High Court upheld their application and a notice was issued to the families to vacate the land voluntarily, but they failed to do so. An enforcement order was subsequently issued, which the Sheriff of the High Court, with the assistance of the police, acted on to demolish the houses of the defendants and order them to vacate the land.

The defendants applied to the High Court seeking a stay of the enforcement orders due to 'maladministration by the Commissioner of Lands, no payment of stamp duty, and the issue of right of occupation'. The defendants claimed that they 'were not given sufficient time to prepare before vacation, and the manner in which the eviction orders were carried out was contrary to their rights and freedom from forced eviction' (Kee $v$. Matefaka). Edward Matefaka, a spokesperson for the families, claimed that they had 'submitted applications to the Commissioner of Lands', but while their 'applications are still pending before the Commissioner of Lands ... two foreigners' have come in and 'out rightly acquired the land' (Theonomi 2014). Matefaka questioned 'whether Solomon Islanders are entitled to apply for state land and why the two foreigners-is it because of money?' The actions of the agents of the state can easily translate into a conflict between the settlers and the state, particularly when the police are involved and perceived to be protecting the property interests of foreigners.

Despite the circumstances surrounding the way in which the land was acquired, the implicit force sanctioned by the court, as a process of exclusion, which was used by the agents of the state to evict the settlers, indicate that the Commissioner of Lands' land dealings are legal unless challenged otherwise on the basis of fraud or mistake. ${ }^{7}$ The High Court upheld the property rights of the two investors, since they were the titleholders of the registered interest in the land, and ordered the eviction of the settlers.

Administration and management of Crown land is a function vested in the Commissioner of Lands and the Registrar of Titles. That function includes the allocation and grant of titles and can only be questioned through the Court challenging the validity of a title. Whoever is occupying Crown land

7 See Section 229, Land and Titles Act. 
without going through the formal processes, and without the consent and approval of the Commissioner of Lands, occupies that land illegally and can be forced to vacate it in the event of resistance or unwillingness to do so.

\section{Powers of Counter-Exclusion in Contemporary Honiara}

\section{Legitimation}

Hall, Hirsch and Li describe legitimation as 'establishing the moral basis for exclusive claims' (Hall et al. 2011:5). They see legitimation playing a central role in counter-exclusions, which they define as 'collective mobilisation by groups of people seeking to counter their exclusion from land as territory or productive resource, and to assert their own powers to exclude' (ibid.:170). Attempts to counter the powers of exclusion that we have already elucidated, including the historical alienation of the land on which Honiara now sits, have seen the deployment of two overarchingand competing-discursive narratives, each of which seeks to establish a morally legitimate claim to property rights in Honiara. On one hand, Malaitan settlers cast themselves as 'workers and builders of the nation, thereby linking themselves to the legitimacy of the state and its broader modernising project' (Allen 2012:172), while on the other, 'a Guale "landowner" narrative invokes indigeneity as the paramount fount of legitimacy in the spheres of land and resource development' (ibid.:164). While Allen describes these competing discourses of legitimation in the context of the Ethnic Tension, with a particular focus on rural areas east and west of Honiara, we suggest that they are also discernible in the context of Honiara itself. Moreover, the strategies that are being deployed to counteract urban exclusion are inflected by Solomon Islands' political economy, as well as by local histories and social relations.

We have already seen that historical patterns of rural-urban migration explain why a significant proportion of settlers who have occupied land in Honiara are from Malaita. Allen $(2012,2013)$ describes how Malaitan identity narratives are embedded in the history of labour relations. Due to historical patterns of uneven development, and the lack of economic opportunities on Malaita, Malaitans have a long history of labour migration that stretches back to the international labour trade of the 19th and early 20 th centuries. It is with some legitimacy, then, that Malaitans 
portray themselves as the workers and builders of Solomon Islands. In the wake of the Ethnic Tension, Malaitans have been reluctant to return to rural Guadalcanal. However, as Allen argues, their identity narrative nevertheless remains tied to the legitimacy of the state:

The state underpins the rights of Malaitans to live within the Honiara town boundary-where they continue to comprise a significant proportion both of the urbanised elite and the town's overall population (Allen 2012:175).

A recent development that fits neatly into this nation-building and modernising narrative is the appeal by settlers in Honiara to the colonial concept of 'waste land'. This concept was introduced as part of the early colonial government's land policy, both to regulate land speculation and to make land available to investors. Section 10 of the Solomons (Land) Regulation No. 4 of 1896 defined waste land as 'land being vacant by reason of the extinction of the original native owners and their descendants'. Following the enactment of the Waste Land Regulation of 1900, as amended by Queen's Regulation No. 1 of 1901, repealed and consolidated by Queen's Regulation No. 2 of 1904, the definition of waste land was amended to mean land that was not owned, cultivated or occupied by any native (see Bennett 1987:131; see also Foukona 2007). The legal implication of this was that more land in the Protectorate became available for acquisition and alienation. This process contributed to the transformation of customary land into state land in Honiara.

Today the term 'waste land' is no longer recognised in law, but some settlers, mainly from Malaita, are still using the concept to assert their claim to vacant spaces in Honiara. ${ }^{8}$ To some of these settlers, waste land is perceived as land that is not needed by Guadalcanal landowners or land in and around Honiara that is underdeveloped. In other words, some settlers justify their claims by asserting that, since the land is waste land, it is all right to occupy and build on it because it is not useful for any other development purpose. The fact that people continue to consider areas such as swampy places, valleys, river banks or steep gullies as waste land to legitimise their land claims is a basis for future land exclusion and contestation (Chand and Yala 2008).

8 This view is often expressed by settlers from Malaita who have recently built informal houses on undeveloped urban land situated in valleys and swampy areas, such as behind the King George and Panatina Ridge east of Honiara. 
In many instances, the Commissioner of Lands has knowledge of these occupiers, who are usually defined in law as squatters, but the fact that they have remained on the land for a long period could constitute a possessory title. ${ }^{9}$ Some of these occupiers have applied to the Commissioner of Lands for a grant of fixed-term estate title to the land. Others believe that, if they are ordered to vacate the land they have occupied for a long period of time, the Commissioner of Lands, as an agent of the state, and the Honiara Town Council would come up with a scheme to relocate them. ${ }^{10}$

In the post-conflict context, some settlers are also attempting to justify their claims to urban land over which they do not hold registered titles on the basis of being displaced by the Ethnic Tension: to evict them, they claim, would cause another displacement. ${ }^{11}$ Such a strategy is reinforced by the fact that most informal settlements in Honiara are based on provincial or island affiliations, which creates a strong sense of group identity, security and protection. ${ }^{12}$ Therefore, anyone who holds a legal title to a plot of land in Honiara that is occupied by settlers may find it difficult to assert their claim, either through legal means or by extrajudicial force. While going through the courts to obtain an eviction order is possible, as we have already seen, enforcing such an order in practice, and getting people to recognise it, is a difficult process that can create additional tensions.

The proposal by the Solomon Islands National Sports Council (NSC) to build a national sports stadium in the Burns Creek area is a case in point. The NSC acquired the perpetual estate title to land in this area that was occupied by settlers three years ago. The Solomon Star newspaper reported that in 2012 the settlers were 'given some time to leave their homes since the NSC took title over the proposed land but have not done so since then' (Anon. 2012). The settlers continued to reside on the land, and recently, with the financial help of their member of parliament (MP), they built a clinic right in the middle of the land that the NSC had earmarked for a playing field. This seemingly reinforced the settlers' perception that, if an MP can fund the building of a clinic on the land, then it is legitimate for them to continue occupying it. The NSC criticised the MP for failing to consult the Honiara City Council to ascertain the legal status of the land before funding the construction of the clinic

9 Section 225 of the Land and Titles Act deals with the principles of adverse possession.

10 See, for example, Onika v. Sevesi (2007) SBHC 57.

11 This was the view by some settlers who moved from the Guadalcanal Plains to Malaita during the Ethnic Tension and then relocated to the Burns Creek area, east of Honiara.

12 Connell and Curtain (1982:119-36, 127) made similar observations in Port Moresby and Lae. 
building (Aruwafu 2012). In October 2013, the NSC revealed that the sport stadium's 'actual ground work could not eventuate as proposed, due to settlers refusing to leave the land earmarked for the stadium despite the call to relocate' (Anon. 2013).

Another example of an MP assisting settlers to assert their property rights concerned a block of public land opposite the White River betel nut market in 2013. Reef islanders from Temotu Province have occupied the land in question for the past 20 years and have named it Karaina settlement (Palmer 2013). The settlers were aware that they did not have tenure security and could be excluded from the land by any private person or company who acquires the legal title to it. The MP claimed that the settlers had asked him to register the land during his campaign in 2010, and he promised them that he would attempt to do so if he became an MP. The Commissioner of Lands made a grant out of a perpetual estate over the land by vesting a fixed-term estate title held in trust by three prominent members of the Karaina settlement: the ward councillor, the Honiara City mayor and the West Honiara MP (Palmer 2013). This land transaction was fast-tracked and enabled by the fact that an MP was engaged in the process, which suggests that the behaviour of the Commissioner of Lands is influenced by patronage politics.

Those people who do not have the requisite patronage networks to secure access to urban land have also adopted the strategy of building as fast as they can on any vacant plot of land that they identify in Honiara, even in the absence of any building permit approval from the Town and Country Planning Board (Diisango 2016). These vacant plots of land are public or alienated land for which the Commissioner of Lands holds perpetual estate titles from which fixed-term estates can be created. ${ }^{13}$ Not many people who have built on these vacant plots of land have been able to acquire fixed-term estates due to a highly bureaucratic land transfer process and high land lease prices (see Keen and Kiddle 2016). Some settlers who can afford such high costs have paid brokers or middlemen, often referred to as 'land consultants', who are familiar with the system of transferring land or have connections with officers in the Ministry of Lands, Housing and Survey to fast-track the process of land transfer.

13 The Commissioner's power to deal with estates has now been transferred to a Land Board under the Land and Titles (Amendment) Act 2014. 
Turning now to the strategies of counter-exclusion employed by indigenous people on Guadalcanal in relation to the land that hosts Honiara, we have already seen that the colonial-era land alienations that ultimately enabled the establishment of the city have been contested since the 1920s. In the postcolonial period, the return of, or compensation or rent for the use of, these lands—especially the area from Lunga to Tenaru-have featured prominently in a succession of formal demands that have been put to the national government by the Guadalcanal Provincial Government, most recently in the form of the 'demands by the bona fide and indigenous people of Guadalcanal' that were issued in January 1999 (see Fraenkel 2004:197-203; also Sasako 2003). These demands, and the discourses of indigeneity that have framed them, operate at the scale of the island of Guadalcanal. They can be interpreted as part of a broader ethno-territorial agenda that seeks to exclude the rights of outsiders, including the state, in matters of resource access and control on Guadalcanal (Allen 2012). This agenda was one of the key underlying causes of the violent land evictions that occurred during the Ethnic Tension.

However, this island-scale ethno-territorial project is deeply problematised by territorial ambitions and agendas that operate at lower scales of sociopolitical organisation, specifically at the scale of customary landownership. Originally postulated by Filer (1997), the ideology of customary landownership' has become an increasingly pervasive and powerful strategy of territorialisation and exclusion throughout postcolonial Melanesia. In the case of Honiara, there have been claims and counter-claims among Guadalcanal landowners and there have also been tensions between the Guadalcanal Provincial Government and individual landowner claimants.

For example, a chief called Andrew Kuvu, representing Guadalcanal indigenous tribal groups, asserted their ownership of land from Lunga to Tenaru (Anon. 2011), but another local man, Andrew Orea, alleged that Kuvu was illegally harvesting cocoa and coconut from this land and that another landowner, Jemuel Guwas, was selling plots of land from within this contested area (Orea 2009). Another landowner, George Vari, who was chairman of the Lunga-Tenaru Trust Board, challenged the claim by Guadalcanal provincial leaders that Lunga land belongs to the province and its people, and asserted that it belongs to the Malango people (Vari 2012). These claims and counter-claims demonstrate that Guadalcanal people, despite drawing on the 'ideology of customary landownership', are not one entity and, in any case, their ownership claims are without 
any legal basis. The property rights to the Lunga-Tenaru land, which is part of the Tenavatu estate, is vested in Levers Solomon Limited. With the consent of the state, Levers can sell the rights to this fixed-term estate to any private individual or investor, which entails the exclusion of Guadalcanal landowners.

\section{Force}

As previously discussed, there exist, both historically and in the contemporary context, multiscalar ethno-territorialising agendas in relation to Honiara. While there is no immediate evidence that these agendas will be pursued through some form of collective violence, the grievances that underscore them continue to be voiced by the Guadalcanal Provincial Government, by prominent Guadalcanal landowners and by a wider network of leaders throughout the province (see Babasia 2014; Leni 2014). Given the persistence of these grievances, and in the wake of the violent evictions that occurred on north Guadalcanal during the Ethnic Tension, a spectre of ethno-territorial violence hangs over all of Honiara. However unlikely a return to widespread violence may be, the possibility that these longstanding agendas may lead to collective violence aimed at reclaiming Honiara cannot be entirely discounted (Anon. 2014a, 2014b).

Moreover, within Honiara itself, settlements are widely perceived as violent spaces in which alcohol and drug abuse are widespread and acts of interpersonal and group violence are commonplace. ${ }^{14}$ As mentioned previously, the threat of force is ever present and may act as a deterrent to those seeking to enforce property rights in settlement areas, including the state's security apparatus. In this sense, settlers' claims to rights of occupation or possession are backed by a spectre of violence. This threat of force is given greater weight, as well as an explicitly political dimension, by a number of well-documented cases of settlement youth being mobilised in overt acts of collective violence on the streets of Honiara. During the riots of April 2006, this collective violence effectively brought down the government of the day (see Dinnen 2007; Moore 2007). In this sense, Honiara's settlements are politically powerful spaces, at least for those political elites who are able to harness the energy and frustration of their younger residents.

14 One example would be the conflict between two ethnic groups in the Karaina settlement, situated in the White River area in western Honiara (Inifiri 2014). 


\section{Conclusion}

In this chapter we have applied the Powers of Exclusion framework to an analysis of the processes by which both settlers and those 'indigenous' to the island of Guadalcanal have been prevented from accessing urban land, and to the strategies that the subjects of this exclusion have been employing to claim, or claim back, access to land within the city boundaries. We have found that the framework is broadly useful in explaining these dual processes and we arrive at a broadly similar set of conclusions as Hall, Hirsch and $\mathrm{Li}$. With regard to the powers of exclusion: the formal rules have tended to bear little resemblance to on-the-ground realities; public officials have frequently acted as tyrants in the administration of land; and the market for land is not a product of some abstract space of supply and demand. In regard to the powers of counter-exclusion, legitimation has played a central role, as evidenced by collective mobilisations around discourses such as indigeneity, customary landownership, nation-building and citizenship. We have also argued, against the backdrop of the Ethnic Tension and the increasingly violent character of Honiara's settlements, that force, in the form of collective violence or the threat thereof, may yet become more salient as a power of counter-exclusion in this urban space.

However, just as the Powers of Exclusion framework is tailored to the particular political economy and social contexts of Southeast Asia, diverse as they are, so too, we have suggested, the powers of exclusion and counterexclusion at play in contemporary Honiara can only be fully understood in the context of an encompassing political economy characterised by patronage networks and personalised forms of political and administrative governance, and with reference to the particular histories and social relations of Solomon Islands. Perhaps the most salient example of this political economy has been the abuse of discretionary powers vested in the Commissioner of Lands, which has seen property rights in urban land allocated in ways that distort the market and abrogate formal legal procedures. In many instances, the abuse of these powers has seen urban property rights granted to individuals on the basis of political patronage or to foreign investors for personal economic gain.

The circumstances surrounding the way that these land transactions are made are often perceived as dubious by members of the public and contrary to the expectations of occupiers. With the 2014 amendment to the Land and Titles Act, which abolishes the Commissioner's powers and 
establishes a Land Board to administer and lease land, it is anticipated that a more transparent leasing process will be introduced. It is hoped that questionable land dealings will be minimised since the discretionary power to create property rights vests in a board rather an individual who can easily be manipulated or bribed. The board came into operation in December 2014 and produced an annual report for 2015 that was tabled in parliament in May 2016 and has recently been made accessible to the public. The report provides a list of land allocations and the names of successful applicants (GoSI 2016). This demonstrates a degree of transparency in the board's deliberations. However, there are no records of minutes concerning how the board has dealt with the applications, including in relation to the criteria used to assess them. Furthermore, the issue of the high cost of land transactions has remained, which means that in most cases only those with money can afford to successfully apply for urban land in Honiara. Some of the applicants to whom the board has allocated land, as shown in the annual report, have revealed that they have not been able access the land. This is because boundary markers have been moved, the land is already occupied by someone else, or officers in the Ministry of Lands have been unhelpful in showing where the land is located and facilitating its transfer.

\section{References}

Allan, C.H. 1957. Customary Land Tenure in the British Solomon Islands Protectorate: Report of the Special Lands Commission. Honiara: Western Pacific High Commission.

Allen, M.G. 2012. Land, Identity and Conflict on Guadalcanal. Australian Geographer 43:163-80. doi.org/10.1080/00049182.2012.682294

Allen, M.G. 2013. Greed and Grievance: Ex-Militants' Perspectives on the Conflict in Solomon Islands, 1998-2003. Honolulu: University of Hawai i Press (Topics in the Contemporary Pacific 2).

Allen, M.G. and S. Dinnen 2015. Solomon Islands in Transition? Journal of Pacific History 50:381-97. doi.org/10.1080/00223344. 2015.1101194

Anon. 1964. Native Claim to Honiara Land Rejected. Pacific Island Monthly, April.

Anon. 2011. Landowners Caution. Solomon Star (Editorial), 4 July.

Anon. 2012. NSC to Put in Work Plan. Solomon Star (Editorial), 27 June. 
Anon. 2013. NSC Powerless. Solomon Star (Editorial), 30 October.

Anon. 2014a. Gov't Urged to Fix Boundary Issue. Solomon Star, 23 August.

Anon. 2014b. Tandai Landowners Slash Demarcation Proposal. Solomon Star, 17 September.

Aruwafu, C. 2012. NSC: Ete’s Excuse Lame. Solomon Star, 24 October.

Babasia, E. 2014. Lunga Land. Solomon Star, 25 June.

Bellam, M.E.P. 1970. The Colonial City: Honiara, a Pacific Islands Case Study. Pacific Viewpoint 11(1):66-96.

Bennett, J.A. 1987. Wealth of the Solomons: A History of a Pacific Archipelago 18001978. Honolulu: University of Hawai'i Press (Pacific Islands Monograph 3).

BSIP (British Solomon Islands Protectorate) 1968. BSIP News Sheet, 1-14 February.

Chand, S. and C. Yala 2008. Informal Land Systems within Urban Settlements in Honiara and Port Moresby. In AusAID (Australian Agency for International Development) (ed.), Making Land Work_Volume Two: Case Studies on Customary Land and Development in the Pacific. Canberra: AusAID.

Connell, J. 1983. Migration, Employment and Development in the South PacificCountry Report 16: Solomon Islands. Noumea: South Pacific Commission.

Connell, J. and R. Curtain 1982. The Political Economy of Urbanization in Melanesia. Singapore Journal of Tropical Geography 3:119-36. doi.org/ 10.1111/j.1467-9493.1982.tb00235.x

Dawea, E. 2013. Councillor Wants Development Stopped. Solomon Star, 2 August.

Diisango, S. 2016. Concern over Illegal Settlements. Solomon Star, 28 September.

Dinnen, S. 2007. A Comment on State-Building in Solomon Islands. Journal of Pacific History 42:255-63. doi.org/10.1080/ 00223340701461700

Englund, H. 2002. The Village in the City, the City in the Village: Migrants in Lilongwe. Journal of Southern African Studies 28:137-54. doi.org/10.1080/ 03057070120117015

Filer, C. 1997. Compensation, Rent and Power in Papua New Guinea. In S. Toft (ed.), Compensation for Resource Development in Papua New Guinea. Port Moresby: Law Reform Commission (Monograph 6).

Filer, C. 2014. The Double Movement of Immovable Property Rights in Papua New Guinea. Journal of Pacific History 49:76-94. doi.org/10.1080/0022334 4.2013.876158 


\section{UNDERSTANDING OCEANIA}

Foukona, J. 2007. Legal aspects of customary land administration in Solomon Islands. Journal of South Pacific Law 11(1):64-72.

Foukona, J. and D. Paterson 2013. Solomon Islands. In D. Paterson and S. Farran (eds), South Pacific Land Systems. Suva: University of the South Pacific Press.

Fraenkel, J. 2004. The Manipulation of Custom: From Uprising to Intervention in the Solomon Islands. Canberra: Pandanus Books.

Gagahe, N.K. 2000. The Process of Internal Movement in Solomon Islands: The Case of Malaita. Asia-Pacific Population Journal 15(2):53-75.

GoSI (Government of Solomon Islands) 2016. Land Board Annual Report 2015. Honiara: Ministry of Lands, Housing and Survey.

Hall, D., P. Hirsch and T. Li 2011. Powers of Exclusion: Land Dilemmas in Southeast Asia. Singapore: NUS Press.

Hou, T. and D. Kudu 2012. Solomon Islands: Honiara Urban Profile. Nairobi: United Nations Human Settlements Programme (UN-Habitat).

Inifiri, J. 2014. Police Investigation in Karaina Row Start. Solomon Star, 27 August.

Keen, M. and L. Kiddle 2016. Priced Out of the Market: Informal Settlements in Honiara, Solomon Islands. State Society and Governance in Melanesia Program In Brief 2016/28. Canberra: The Australian National University.

Leni, N. 2014. Extension of City Boundary. Solomon Star, 22 September.

McDonnell, S. 2013. Exploring the Cultural Power of Land Law in Vanuatu: Law as a Performance That Creates Meaning and Identities. Intersections 33.

Moore, C. 2007. Helpem Fren: The Solomon Islands, 2003-2007. Journal of Pacific History 42:141-64. doi.org/10.1080/00223340701461601

Moore, C. 2013. Honiara. In C. Moore (ed.), Solomon Islands Historical Encyclopaedia 1893-1978. St Lucia: University of Queensland. www.solomon encyclopaedia.net/biogs/E000133b.htm (accessed 13 April 2014).

Moore, C. 2015. Honiara: Arrival City and Pacific Hybrid Living Space. Journal of Pacific History 50:419-36. doi.org/10.1080/00223344. 2015.1110869

Namosuaia, D. 2013. Land Risk. Solomon Star, 7 June.

Namosuaia, D. 2014. Mass City Clean-Up-Council Sets to Demolish Illegal Buildings. Solomon Star, 31 January.

Orea, A.S. 2009. Who is Kuvu? Solomon Star, 15 December. 
Palmer, E. 2010. Land Row ... Guadalcanal Wants to Be Part of Lungga Land Sale. Solomon Star, 31 March.

Palmer, E. 2013. Tran Acquire Title for Karaina Settlement. Solomon Star, 17 October.

Pelto, M. 2013. High Value Urban Land in Honiara For Sale-Deep, Deep Discounts Available to the Right Buyer. Devpolicy blogpost, 16 December. devpolicy.org/high-value-urban-land-in-honiara-for-sale-deep-deepdiscounts-available-to-the-right-buyer-20131214/ (accessed 12 December 2016).

Piringi, C. 2013a. Defying Orders. Solomon Star, 10 October.

Piringi, C. 2013b. Maeli Hits Back. Solomon Star, 14 October.

Sasako, A. 2003. The Day and Forces that Changed Solomon Islands. Fiji Islands Business, July.

Storey, D. 2003. The Peri-Urban Pacific: From Exclusive to Inclusive Cities. Asia Pacific Viewpoint 44:259-79. doi.org/10.1111/j.1467-8373.2003.00214.x

Theonomi, B. 2014. More Houses Demolished: Families Left Homeless as Police Tear Down Homes. Solomon Star, 18 June.

Tozaka, M. and J. Nage 1981. Administering Squatter Settlements in Honiara. In P. Larmour, R.G. Crocombe and A. Taungenga (eds), Land, People and Government: Public Lands Policy in the South Pacific. Suva: University of the South Pacific, Institute of Pacific Studies, in association with Lincoln Institute of Land Policy.

Vari, G. 2012. Lunga Land Ownership. Solomon Star, 16 May.

Williams, S. 2011. Public Land Governance in Solomon Islands. Washington, DC: World Bank, Justice for the Poor Program (Briefing Note 6:1).

WPHC (Western Pacific High Commission) n.d. Land Claims, Register B. Auckland: University of Auckland (Special Collection WPHC MP 18/1/2).

WPHC (Western Pacific High Commission) 1922. British Solomon Islands Commission Claim No. 17-Matanikau, Kookom. Auckland: University of Auckland (Special Collection WPHC 4/IV, MP 450/1922).

Zoleveke, G. 1979. Traditional Ownership and Land Policy. In P. Larmour (ed.), Land in Solomon Islands. Suva: University of the South Pacific, Institute of Pacific Studies. 
This text is taken from Understanding Oceania: Celebrating the University of the South Pacific and its collaboration with The Australian National University, edited by Stewart Firth and Vijay Naidu, published 2019 by ANU Press, The Australian National University, Canberra, Australia.

doi.org/10.22459/UO.2019.15 